\title{
Przestępczość w Państwie Ukraińskim w okresie koniec lipca - sierpień 1918 r. - analiza na podstawie wybranych materiałów Centralnego Państwowego Archiwum Wyższych Organów Władzy i Administracji Ukrainy w Kijowie
}

Zarys treści: Celem artykułu jest przedstawienie zagadnienia przestępczości w Państwie Ukraińskim rządzonym przez hetmana Pawła Skoropadskiego. Tekst powstał w oparciu o dokumenty archiwalne znajdujące się w Centralnym Państwowym Archiwum Wyższych Organów Władzy i Administracji Ukrainy w Kijowie. Ich cezury obejmują lipiec i sierpień 1918 r. Zawierają one szereg informacji dotyczących przestępstw na terytorium Państwa Ukraińskiego, m.in. czas i miejsce popełnienia zbrodni czy wykorzystane przez organy ścigania i śledczych środki zapobiegawcze.

Outline of content: The article aims to present the topic of crime in the Ukrainian State ruled by Hetman Pavlo Skoropadsky. The text was based on archival documents found in the Central State Archives of Supreme Bodies of Power and Government of Ukraine in Kyiv. Their periods are from the end of July to August 1918. The documents contain specific information about crimes committed in the territory of the Ukrainian State, including time and place of committing a crime or preventive measures used by law enforcement and investigative authorities.

Słowa kluczowe: Ukraina, Państwo Ukraińskie, historia ukraińskiego sądownictwa, historia ukraińskich organów ścigania, historia przestępczości, historia państwa i prawa

Keywords: Ukraine, Ukrainian State, history of judicial system of Ukraine, history of law enforcement authorities, history of crime, history of law and statehood 
W czołówce słabo opracowywanych tematów dotyczących historii Ukrainy w latach tzw. I rewolucji narodowej (1917-1921) znajduje się zagadnienie przestępczości i jej zwalczania. Najczęściej ukraińscy badacze, którzy zresztą jako niemal jedyni podejmowali tematy z zakresu państwa i prawa Ukrainy z tamtego okresu, skupiali się na formowaniu sądownictwa i innych organów władzy, nie zagłębiając się zbytnio $\mathrm{w}$ interesujące mnie zagadnienie. Problem łamania prawa przez ludność cywilną w tym "gorącym okresie" nie znalazł się dotychczas szerzej w kręgu zainteresowania badaczy.

Tematem niniejszego tekstu jest przestępczość w Państwie Ukraińskim ${ }^{1}$ hetmana Pawła Skoropadskiego ${ }^{2}$ w okresie koniec lipca - sierpień 1918 r., w świetle wykazów jednego z departamentów Ministerstwa Sprawiedliwości. Jako główne źródła posłużyły dokumenty archiwalne z jednej z teczek Centralnego Państwowego Archiwum Wyższych Organów Władzy i Administracji Ukrainy w Kijowie. Ograniczenie cezur do okresu lipiec-sierpień 1918 r. wynika głównie z wyboru źródeł odnalezionych w powyższym archiwum. Wykazy I Departamentu Ministerstwa Sprawiedliwości obejmują niestety tylko ten skromny czasowo, acz intensywny i brutalny okres istnienia Państwa Ukraińskiego (koniec kwietnia - połowa grudnia 1918 r.). Celem zweryfikowania rzetelności tychże dokumentów skonfrontowano je z raportami i komunikatami z innych teczek z kijowskiego archiwum oraz zawartością jednego z cennych wydawnictw źródłowych ${ }^{3}$.

Należy podkreślić, że w tekście niejednokrotnie stosowano terminy „przestępstwo" i „zbrodnia”. Pierwszy termin jest bardzo abstrakcyjny i obejmuje wszelkie czyny szkodliwe społecznie oraz popełnione wbrew obowiązującemu prawu.

1 Украйнська Держава (квітень-грудень 1918 року). Документи і матеріали. У двох томах, т. 1-2, ред. В. Смолій, Київ 2015; П. Феденко, Влада Павла Скоропадского (пятьдесяті роковини перевороту в Україні), Лондон-Мюнхен 1968; П. Гай-Нижник, Фінансова політика уряду Української Держави Гетьмана Павла Скоропадського (29 квітня 14 грудня 1918 р.), Київ 2001; Д. Дорошенко, Історія України 1917-1923 рр., т. 2: Українська Гетьманська Держава 1918 р., Київ 2002; Д. Яневський, Проект „Україна” або спроба Павла Скоропадського, Харків 2010; Р. Пиріг, Українська гетманська держава 1918 року. Історичні нариси, Київ 2011.

2 Pawło Skoropadski (1873-1945), ukraiński arystokrata i generał-lejtnant armii rosyjskiej. W młodości należał do Korpusu Paziów, a także był adiutantem cesarza Mikołaja II Romanowa. W 1917 r. objął dowództwo nad 34 Korpusem na Froncie Południowo-Zachodnim. Latem poddał podległe mu zgrupowanie ukrainizacji. W październiku 1917 r. został mu nadany tytuł honorowego atamana Wolnego Kozactwa na zjeździe tej organizacji w Czehryniu. Od 29 kwietnia do 14 grudnia 1918 r. rządził Ukrainą jako hetman Państwa Ukraińskiego. Po udanym buncie zorganizowanym przez ukraińskich republikanów i socjalistów wyjechał do Niemiec, zob. П. Скоропадський, Спогади. Кінець 1917-грудень 1918, Київ-Філадельфія 1995; А. Кущинський, Патріот і державний муж України. У 100-річчя з дня народження Гетьмана усієї Украйни і Військ Козацьких Павла Скоропадського та 55-ої річниці відновлення Української Традиційної Гетьманської Держави, Чикаго 1974; Г. Панакін, Павло Скоропадський. патріот, державотворець, людина. Історико-архівні нариси, Київ 2003.

3 Архів Української Народної Республіки. Міністерство внутрішніх справ. Звіти департаментів державної варти та політичної інформації (1918-1922), упор. В. Кавунник, Київ 2018. 
Drugi odnosi się do węższego kręgu czynów zabronionych, tych najcięższych, np. morderstwo, gwałt. Swoją uwagę skupiłem na przestępstwach, które we współczesnej Polsce byłyby przeważnie objęte ściganiem na podstawie prawa karnego i karnego skarbowego. W przypadku Państwa Ukraińskiego do kategorii „zbrodni” zaliczono jednak i takie przestępstwa, jak kradzieże o dużych rozmiarach. Ponadto w Hetmanacie jako „zbrodnie” postrzegano akty niezbrojnego oporu społecznego, np. strajki. Wpływ na taki stosunek organów sądownictwa i ścigania miał fakt inspirowania się przez władze państwa rozwiązaniami przedrewolucyjnego prawa Imperium Rosyjskiego.

Na przełomie 1917 i 1918 r. doszło do wykrystalizowania się niezależnej państwowości ukraińskiej. 25 stycznia ukraińska Centralna Rada ogłosiła IV Uniwersał, w którym proklamowano niepodległość Ukraińskiej Republiki Ludowej (URL) ${ }^{4}$. W tym czasie trwała już w pełni niewypowiedziana wojna ukraińsko-bolszewicka, wywołana agresją „czerwonych” z Rosji i nieudaną próbą pochodu zbolszewizowanych jednostek armii rosyjskiej z frontu wschodniego na Kijów. Najsłynniejszymi starciami militarnymi tej wojny były obrona stacji kolejowej Kruty przez nieliczny ukraiński oddział ochotników i studentów ${ }^{5}$ oraz stłumienie probolszewickiego puczu w Kijowie, którego centrum dowodzenia znajdowało się w zakładach Arsenał. W ich cieniu pozostały nie mniej ważne, a na dodatek skuteczne działania zgrupowania gen. Skoropadskiego, który rozbił na Wołyniu bolszewickie oddziały zmierzające $\mathrm{z}$ frontu wschodniego na ukraińską stolicę 9 . 9 lutego $1918 \mathrm{r}$. URL podpisała traktat w Brześciu Litewskim, na mocy którego stała się sojusznikiem państw centralnych (zwanych również czwórprzymierzem): II Rzeszy Niemieckiej, Austro-Węgier, Imperium Osmańskiego i Królestwa Bułgarii. Skutkami zawarcia traktatu były udany antybolszewicki pochód wojsk niemieckich i austro-węgierskich, ale również konieczność zrealizowania zobowiązania, jakie przyjęła w Brześciu Litewskim delegacja Centralnej Rady - dostarczenie ogromnej ilości ton prowiantu (głównie zboża) ${ }^{7}$.

4 Четвертий Універсал Української Центральної Ради, 9 січня 1918, w: Українська Центральна Рада. Документи і матеріали. У двох томах, т. 2: 10 грудня 1917 р. - 29 квітня 1918 р., ред. В. Верстюк та ін., Київ 1997, s. 102-104.

5 Szerzej na temat bitwy pod Krutami zob. Бій під Крутами в національній пам'яті. 3бірник документів і матерліалів, ред. О. Любовець, О. Березовський, С. Бутко, А. Тищенко, І. Цимбал, Київ 2013; І. Л-ий [І. Лоський], Крути, „Літопис Червоної Калини” (1932), № 2, s. 2-5; А. Гончаренко, Бій під Крутами, „За державність” 9 (1939), s. 145-152; А. Крезуб [О. Думін], „Українські Термопілі” (в десяту річницю бою під Крутами), „Літературно-Науковий Вістник” 28 (1928), № 2, s. 105-109; О. Удовиченко, Загибель студентського куреня під Крутами, „Військова Справа” (1928), № 2, s. 5-8; А. Фіголь, Бій під Крутами, „Літопис Червоної Калини” (1931), № 2, s. 2-6; Крути 29 січня 1918 р., ред. О. Бойко, Київ 2007; Героїка трагедії Крут, ред. В. Сергійчук, Київ 2008.

6 Я. Тинченко, Українські зброцнні сили: березень 1917 - листопад 1918 р. (організація, чисельність, бойові діi), Київ 2009, s. 22-29.

7 Мирний договір між Німеччиною, Туреччиною, Австро-Угорщиною, Болгарією та Українською Народною Республікою, 27 січня 1918 р.; Текст додаткового договору міх УНР і країнами Четверного Союзу, 27 січня 1918 р., w: Украйнська Центральна Рада..., т. 2, s. 137-150. 
Liczne problemy $\mathrm{z}$ wywiązaniem się $\mathrm{z}$ powyższego zobowiązania oraz porewolucyjny i powojenny chaos na Ukrainie, $\mathrm{z}$ którymi również nie były $\mathrm{w}$ stanie natychmiast uporać władze URL, skłoniły Niemców do szukania zastępstwa dla Centralnej Rady. Ostatecznie zdecydowano się na poparcie wspomnianego wyżej gen. Skoropadskiego. Przy życzliwej neutralności wojsk niemieckich dokonał on 29 kwietnia 1918 r. zamachu stanu i proklamował powstanie Państwa Ukraińskiego w miejsce URL. Sam przyjął tytuł hetmana i posiadał w zasadzie autorytarne uprawnienia. W Państwie Ukraińskim nie istniał trójpodział władzy. Władzę wykonawczą i ustawodawczą sprawowali hetman i Rada Ministrów, którzy na dodatek mieli kontrolę nad sądownictwem ${ }^{8}$.

Po swojej „ludowej” poprzedniczce Państwo Ukraińskie „odziedziczyło” m.in. ogromny chaos $\mathrm{w}$ sądownictwie i spore problemy $\mathrm{z}$ przestępczością. W pierwszych miesiącach istnienia nowej państwowości chaos prawny wywoływało mieszane sądownictwo - w tym samym czasie funkcjonowały sądy byłego Imperium Rosyjskiego, Rządu Tymczasowego, stworzone przez Centralną Radę, oraz Hetmanat - a także różne źródła prawa (z okresu przedrewolucyjnego, wydane przez URL, jak i nowe władze). Hetman Skoropadski wspierał działalność sądów przedrewolucyjnych, gdyż planował w ramach swych reform upodobnić ukraińskie sądownictwo do tego, które istniało w Imperium Rosyjskim. Oznaczało to zarazem skopiowanie wielu rozwiązań z prawa rosyjskiego, $w$ tym np. przekazanie pieczy nad śledztwem sędziom śledczym w poszczególnych powiatach, o czym wspomniano wyżej9.

Do zwalczania przestępczości powołano drogą ustawy z dn. 18 maja $1918 \mathrm{r}$. nowy organ ścigania i bezpieczeństwa, który zastąpił republikańską milicję. Nosił on nazwę Warty Państwowej (Державна Варта). Początkowo w jej skład wchodziły przemianowane miejskie i powiatowe milicje, sformowane jeszcze w okresie rządów Centralnej Rady. Warta Państwowa była podporządkowana starostom szczebla guberni i powiatu, którzy mieli duży wpływ na obsadę stanowisk

\footnotetext{
${ }^{8}$ П. Феденко, ор. cit., s. 5-7; W. Mędrzecki, Niemiecka interwencja militarna na Ukrainie w 1918 roku, Warszawa 2000, s. 157-159; О. Рум'янцев, Судова система в Украӥнській державі гетьмана П. Скоропадського, „Вісник Академії правових наук України” (2001), № 2 (25), s. 77-87; Ю. Терещенко, Гетьманат Павла Скоропадського як прояв консервативної революціï, w: Гетьманат Павла Скоропадського. історія, постаті, контроверсіі. Всеукраїнська наукова конференція 19-20 травня 2008 р., ред. В. Верстюк, Київ 2008, s. 21; G. Skrukwa, Formacje wojskowe ukrainskiej „rewolucji narodowej” 1914-1921, Toruń 2008, s. 268-269; В. Головченко, В. Солдатенко, Украйнське питання в роки Першої світової війни, Київ 2009, s. 265-266; В. Дорнік, Г. Касьянов, П. Ліб, Г. Ляйдінгер, А. Міллєр, Б. Мусял, В. Расевич, Україна між самовизначенням та окупацією: 1917-1922 роки, Київ 2015, s. 245-246; Р. Пиріг, Відносини України і Центральних держав. Нетипова окупація 1918 року, Київ 2018, s. 30.

9 О. Рум'янцев, op. cit., s. 77-78; І. Гуцалюк, Суд та судочинство в Західній Волині за Гетьманату П. Скоропадського, „Науковий вісник Волинського національного університету імені Лесі Українки. Історичні науки" (2010), № 1, s. 50-53.
} 
kierowniczych nowej formacji. Warta powinna być finansowana $\mathrm{z}$ budżetu Ministerstwa Spraw Wewnętrznych ${ }^{10}$.

W Państwie Ukraińskim podjęto próbę skatalogowania najcięższych przestępstw karnych popełnionych na jego terytorium. W tym celu I Departament Ministerstwa Sprawiedliwości wysyłał od 5 sierpnia 1918 r. sporządzony wykaz informacji o dokonanych zbrodniach. Każdy kolejny raport obejmował okres ok. tygodnia. Zawierał informacje o czasie doniesienia o popełnionym przestępstwie, jego rodzaju, śledczych sądowych prowadzących postępowania oraz o środkach zapobiegawczych (np. areszt) użytych wobec sprawców lub podejrzanych środkach zapobiegawczych ${ }^{11}$.

Treść wykazów zdecydowałem się zaprezentować w formie tabel. Zawierają one - moim zdaniem - najciekawsze informacje dotyczące zbrodni popełnionych na terytorium Państwa Ukraińskiego: czas złożenia doniesienia o dokonaniu przestępstwa do prokuratury, charakterystykę zbrodni (czas, miejsce, sprawcy, ofiary, wyrządzone szkody), przynależność śledczego sądowego, prowadzącego śledztwo, do odpowiedniego okręgu ukraińskiego sądownictwa (np. śledczy sądowy powiatu kijowskiego) oraz aktualny stan postępowania i użyte środki zapobiegawcze (przykładowo: aresztowano 7 sprawców).

10 № 48. Тимчасова постанова про зміну законів про міліцію та утворення Державної варти. 18.05.1918 p., w: Українська Держава..., т. 2, s. 87-88. Więcej informacji na temat tego interesującego organu ścigania można zaczerpnąć z następującej pozycji: О. Тимощук, Державна варта Української Держави (історико-юридичний аналіз), Київ 1998.

11 Центральний Державний Архів Вищих Органів Влади та Управління України у Києві (dalej: ЦДАВОВУ), ф. 2207, о. 1, сп. 825, Відомость № 1 про найбільшважні карні злочинства, заподіяні в межах Української Держави. Складена I Департаментом Міністерства Юстіціi 5 Серпня 1918 року, по представленням осіб прокурорського догляду, надісланним до Міністерства за від 29 липня по 3 серпня 1918 року, k. 1-4; ibidem, Відомость № 2 про найбільшважні карні злочинства, заподіяні в межах Української Держави. Складена I Департаментом Міністерства Юстіціi 12 Серпня 1918 року, по представленням осіб прокурорського догляду, надісланним до Міністерства за від 4 по 10 серпня 1918 року, k. 5-8; ibidem, Відомость № 3 про найбільшважні карні злочинства, заподіяні в межах Української Держави. Складена I Департаментом Міністерства Юстіціі... [brak daty dziennej] Серпня 1918 року, по представленням осіб прокурорського догляду, надісланним до Міністерства за від 11 по 18 серпня 1918 року, k. 9-12; ibidem, Відомость № 4 про найбільшважні карні злочинства, заподіяні в межах Української Держави. Складена I Департаментом Міністерства Юстіціi 27 Серпня 1918 року, по надісланним до Міністерства представленням осіб прокурорського догляду, k. 13-14; ibidem, Відомость № 4 про найбільшважні карні злочинства, заподіяні в межах Української Держави. Складена I Департаментом Міністерства Юстіціi 27 Серпня 1918 року, по надісланним до Міністерства представленням осіб прокурорського догляду, k. 15-16. 
Tabela 1. Wykaz najpoważniejszych zbrodni dokonanych na terytorium Państwa Ukraińskiego w okresie 29 lipca - 3 sierpnia 1918 r.

\begin{tabular}{|c|c|c|c|}
\hline $\begin{array}{c}\text { Dzień rozpoczęcia } \\
\text { postępowania }\end{array}$ & Opis przestępstwa & $\begin{array}{c}\text { Przynależność okręgowa } \\
\text { śledczego sądowego }\end{array}$ & \begin{tabular}{|c|}
$\begin{array}{c}\text { Środki zapobiegawcze użyte przez } \\
\text { organy ścigania i stan postępowania } \\
\text { na dzień sporządzenia wykazu }\end{array}$ \\
\end{tabular} \\
\hline 30 lipca 1918 r. & $\begin{array}{l}30 \text { lipca w Kijowie dokonano zamachu na feldmarszałka Eichorna } \\
\text { i jego adiutanta Dreslera. }\end{array}$ & $\begin{array}{l}\text { Śledczy sądowy powiatu } \\
\text { kijowskiego }\end{array}$ & $\begin{array}{l}\text { Zbrodniarz został zatrzymany. Prowa- } \\
\text { dzono działania zmierzające do odna- } \\
\text { lezienia pozostałych sprawców. }\end{array}$ \\
\hline 30 lipca 1918 r. & $\begin{array}{l}29 \text { lipca w mieście Puszcza-Wodyca koło Kijowa na ulicy miał } \\
\text { miejsce zamach na ministra transportu Borysa Butenkę z uży- } \\
\text { ciem broni palnej. }\end{array}$ & $\begin{array}{l}\text { Śledczy sądowy powiatu } \\
\text { kijowskiego }\end{array}$ & $\begin{array}{l}\text { Złoczyńca nie został schwytany. Za- } \\
\text { trzymano nieznanego mężczyznę, } \\
\text { który został przesłuchany. }\end{array}$ \\
\hline 22 lipca 1918 r. & $\begin{array}{l}12 \text { lipca w Wielkiej Moszczanicy, w powiecie dubieńskim, miał } \\
\text { miejsce napad uzbrojonych włościan na wartowników strzegą- } \\
\text { cych lasu. Zginęło } 2 \text { posterunkowych i } 5 \text { właścicieli nielegalnie } \\
\text { wyrąbywanego przez włościan lasu. Zamordowanym zabrano } \\
50 \text { tys. karbowańców. Niemcy w odpowiedzi zainterweniowali - } \\
\text { ostrzelali wieś z artylerii. Zginęło } 20 \text { mężczyzn. }\end{array}$ & $\begin{array}{l}\text { Śledczy sądowy powiatu } \\
\text { dubieńskiego }\end{array}$ & $\begin{array}{l}2 \text { prowodyrów, byłych marynarzy, zgi- } \\
\text { nęło. } 1 \text {, włościanin, zbiegł. }\end{array}$ \\
\hline 29 lipca 1918 r. & $\begin{array}{l}\text { W nocy z } 28 \text { na } 29 \text { lipca w miasteczku Nosówka, w powiecie } \\
\text { niżyńskim, } 200 \text { uzbrojonych mężczyzn napadło na posterunek } \\
\text { Warty Państwowej. Budynek splądrowano, naczelnika i } 9 \text { poste- } \\
\text { runkowych zabito. }\end{array}$ & $\begin{array}{l}\text { Śledczy sądowy powiatu } \\
\text { niżyńskiego }\end{array}$ & Brak informacji. \\
\hline 1 sierpnia $1918 \mathrm{r}$. & $\begin{array}{l}\text { W Połtawie w nocy z } 29 \text { na } 30 \text { lipca zamordowano byłego Gene- } \\
\text { ralnego Sekretarza Oświaty Iwana Steszenkę. }\end{array}$ & Brak informacji. & Brak informacji. \\
\hline 9 lipca 1918 r. & $\begin{array}{l}\text { W nocy } 2 \text { lipca na Dnieprze miał miejsce napad rabunkowy na } \\
\text { parowiec „Razswiat”. Zrabowano } 50 \text { tys. karbowańców. }\end{array}$ & $\begin{array}{l}\text { Śledczy sądowy powiatu } \\
\text { sośnickiego }\end{array}$ & Sprawców nie zatrzymano. \\
\hline 26 lipca 1918 r. & $\begin{array}{l}\text { W nocy z } 18 \text { na } 19 \text { lipca w powiecie sumskim obrabowano ekono- } \\
\text { mię braci Sawycz. Skradziono konie. }\end{array}$ & $\begin{array}{l}\text { Śledczy powiatu sum- } \\
\text { skiego }\end{array}$ & $\begin{array}{l}\text { Aresztowano włościanina Szewczenkę } \\
\text { podejrzewanego o udział. }\end{array}$ \\
\hline 16 lipca 1918 r. & $\begin{array}{l}9 \text { maja w mieście Lityń na posiedzeniu ziemstwa powiatowego } \\
\text { wniesiono antypaństwową rezolucję. }\end{array}$ & $\begin{array}{l}\text { Śledczy sądowy powiatu } \\
\text { lityńskiego }\end{array}$ & Brak informacji. \\
\hline
\end{tabular}




\begin{tabular}{|c|c|c|c|}
\hline 20 lipca 1918 r. & $\begin{array}{l}\text { W nocy na } 28 \text { lipca w mieście Czarny Ostrów zabito urzędnika } \\
\text { włości }{ }^{12} \text { powiatu płoskirowskiego, Trochima Banaszkę. }\end{array}$ & $\begin{array}{l}\text { Śledczy Sądu Okręgowe- } \\
\text { go Kamieniec Podolski }\end{array}$ & $\begin{array}{l}\text { Aresztowano } 7 \text { sprawców (włościan), } \\
\text { którzy przyznali się do zbrodni. }\end{array}$ \\
\hline 20 lipca 1918 r. & $\begin{array}{l}\text { Naczelnik Miejskiej Warty Państwowej w Charkowie Merkułow } \\
\text { i jego pomocnicy Humanicki oraz Naumenko zostali oskarżeni } \\
\text { o nielegalną rekwizycję i wyprzedanie zrabowanych towarów. }\end{array}$ & $\begin{array}{l}\text { Śledczy charkowskiego } \\
\text { sądu okręgowego Skar- } \\
\text { żyński }\end{array}$ & $\begin{array}{l}\text { Schwytanych sprawców jeszcze nie } \\
\text { przesłuchano. }\end{array}$ \\
\hline 20 lipca 1918 r. & $\begin{array}{l}\text { Przewodniczący Chersońskiego Gubernialnego Zarządu Ziem- } \\
\text { skiego Żywotowski został oskarżony o defraudację } 900 \text { tys. kar- } \\
\text { bowańców z budżetu samorządu. }\end{array}$ & $\begin{array}{l}\text { Śledczy sądowy chersoń- } \\
\text { skiego sądu okręgowego }\end{array}$ & Oskarżony zbiegł. \\
\hline 30 lipca 1918 r. & $\begin{array}{l}25 \text { lipca we włościach awratyńskiej i bazaliwskiej, w powiecie } \\
\text { starokonstantynowskim, wybuchło powstanie chłopskie. Zabi- } \\
\text { to naczelników powiatowej i gminnej Warty Państwowej oraz } 6 \\
\text { posterunkowych. Powstanie zduszono przy wykorzystaniu wojsk } \\
\text { niemieckich i austro-węgierskich. }\end{array}$ & $\begin{array}{l}\text { Śledczy sądowy powiatu } \\
\text { starokonstantynowskiego }\end{array}$ & Brak informacji. \\
\hline 26 lipca 1918 r. & $\begin{array}{l}20 \text { lipca w wiosce Hruszowce, w powiecie rówieńskim, uzbrojeni } \\
\text { włościanie napadli na posterunkowych i leśników oceniających } \\
\text { straty spowodowane nielegalnym wyrębem. } 2 \text { posterunkowych } \\
\text { zginęło. }\end{array}$ & Brak informacji. & $\begin{array}{l}\text { Złoczyńcy uciekli, trwały ich poszuki- } \\
\text { wania przy wsparciu wojska. }\end{array}$ \\
\hline 30 lipca 1918 r. & $\begin{array}{l}\text { W nocy z } 29 \text { na } 30 \text { lipca na trasie kolejowej Żuliany-Post-Wo- } \\
\text { łyński w wyniku wybuchu bomby uszkodzono pociąg pasażerski } \\
\text { nr 30, kierujący się do Odessy. Nikt nie zginął. Ranny został tylko } \\
\text { palacz kotła parowego. }\end{array}$ & $\begin{array}{l}\text { Śledczy sądowy powiatu } \\
\text { kijowskiego }\end{array}$ & Brak informacji. \\
\hline 23 lipca 1918 r. & $\begin{array}{l}20 \text { lipca w Katerynosławiu miał miejsce strajk robotników i ko- } \\
\text { lejarzy. }\end{array}$ & Brak informacji. & $\begin{array}{l}\text { Podejrzani to członkowie komitetu } \\
\text { strajkowego, ale jego skład nie był } \\
\text { w tym czasie znany organom ścigania. }\end{array}$ \\
\hline
\end{tabular}

Źródło: ЦДАВОВУ, ф. 2207, о. 1, сп. 825, Відомость № 1 про найбільшважні карні злочинства, заподіяні в межах Української Держави. Складена I Департаментом Міністерства Юстіціі 5 Серпня 1918 року, по представленням осіб прокурорського догляду, надісланним до Міністерства за від 29 липня по 3 серпня 1918 року, k. 1-4.

12 Włość - ros. волость. Jednostka administracyjna w Imperium Rosyjskim i do 1929 r. w Związku Sowieckim. Odpowiednik gminy. 
Tabela 2. Wykaz najpoważniejszych zbrodni dokonanych na terytorium Państwa Ukraińskiego w okresie 4-10 sierpnia 1918 r.

\begin{tabular}{|c|c|c|c|}
\hline $\begin{array}{l}\text { Dzień rozpoczęcia } \\
\text { postępowania }\end{array}$ & Opis przestępstwa & $\begin{array}{l}\text { Przynależność okręgowa } \\
\text { śledczego sądowego }\end{array}$ & $\begin{array}{l}\text { Środki zapobiegawcze użyte } \\
\text { przez organy ścigania i stan } \\
\text { postępowania na dzień } \\
\text { sporządzenia wykazu }\end{array}$ \\
\hline 22 lipca 1918 r. & $\begin{array}{l}\text { W nocy z } 8 \text { na } 9 \text { lipca grupa ok. } 2000 \text { tys. powstańców, mających na } \\
\text { wyposażeniu } 20 \text { karabinów maszynowych i } 1 \text { lekką armatę polową, } \\
\text { zaatakowała stację kolejową Potap, gdzie stacjonowało } 80 \text { niemiec- } \\
\text { kich żołnierzy. Napastnicy zostali odparci i rozproszyli się. Następnie } \\
\text { zebrali się ponownie w mieście Piatyhory. }\end{array}$ & Brak informacji. & Brak informacji. \\
\hline 30 lipca 1918 r. & $\begin{array}{l}22 \text { czerwca } 4 \text { bandytów napadło na plebanię kapłana Kliasunowa we } \\
\text { wsi Hremżeczka, w powiecie głuchowskim. Zamordowano kapłana } \\
\text { z żoną, ich córka została ranna. Napastnicy zrabowali } 100 \text { karbowań- } \\
\text { ców. }\end{array}$ & $\begin{array}{l}\text { Śledczy sądowy powiatu } \\
\text { głuchowskiego }\end{array}$ & Brak informacji. \\
\hline 6 sierpnia $1918 \mathrm{r}$. & $\begin{array}{l}5 \text { sierpnia o godz. } 11.00 \text { doszło do wybuchu bomby w szatni na stacji } \\
\text { kolejowej nr I w Kijowie. Ranne zostały dwie kobiety. }\end{array}$ & Brak informacji. & Brak informacji. \\
\hline 6 sierpnia $1918 \mathrm{r}$. & $\begin{array}{l}5 \text { sierpnia o godz. } 22.00 \text { doszło do wybuchu bomby w wagonie na } \\
\text { stacji kolejowej nr I w Kijowie. }\end{array}$ & Brak informacji. & Brak informacji. \\
\hline 30 lipca 1918 r. & $\begin{array}{l}21 \text { czerwca i w nocy z } 28 \text { na } 29 \text { czerwca grupa ok. } 50 \text { bolszewików } \\
\text { napadła na majątek ziemianina Becka we wsi Zarucka, w powiecie } \\
\text { głuchowskim. Napastnicy zostali odparci przez kozaków, ale w wyni- } \\
\text { ku walk doszło do spalenia prawie całej miejscowości. }\end{array}$ & $\begin{array}{l}\text { Śledczy sądowy powiatu } \\
\text { głuchowskiego }\end{array}$ & Brak informacji. \\
\hline
\end{tabular}




\begin{tabular}{|c|c|c|c|}
\hline 6 sierpnia $1918 \mathrm{r}$. & $\begin{array}{l}\text { W nocy z } 2 \text { na } 3 \text { sierpnia w pobliżu stacji kolejowej Biała Cerkiew ob- } \\
\text { rabowano obywateli Korobowa i Szmelewa na } 918 \text { tys. karbowańców. }\end{array}$ & Brak informacji. & $\begin{array}{l}\text { Prowadzono postępowanie } \\
\text { przygotowawcze. }\end{array}$ \\
\hline 29 lipca 1918 r. & $\begin{array}{l}6 \text { maja we wsi Seweranowice oraz } 12 \text { maja we wsiach Czerniatyce, } \\
\text { Towarówka i innych miejscowościach w powiecie lityńskim doszło } \\
\text { do agitacji antypaństwowej. }\end{array}$ & $\begin{array}{l}\text { Śledczy sądowy powiatu } \\
\text { winnickiego }\end{array}$ & Aresztowano 21 osób. \\
\hline 22 lipca 1918 r. & $\begin{array}{l}25 \text { marca w Mirgrodzie naczelnik milicji Leszczenko aresztował } \\
\text { i przekazał do sztabu oddziału „hajdamaków” kilku Żydów, którzy } \\
\text { zostali potem zakatowani na śmierć. }\end{array}$ & $\begin{array}{l}\text { Sędzia administracyjny } \\
\text { powiatu mirgrodzkiego }\end{array}$ & Brak informacji. \\
\hline 2 sierpnia $1918 \mathrm{r}$. & $\begin{array}{l}25 \text { lipca w mieście Ładyżyn, w powiecie hajsyńskim, włościanin } \\
\text { Twerdyło występował z krytyką ustroju Państwa Ukraińskiego. }\end{array}$ & $\begin{array}{l}\text { Śledczy sądowy powiatu } \\
\text { hajsyńskiego }\end{array}$ & Brak informacji. \\
\hline 9 sierpnia $1918 \mathrm{r}$. & $\begin{array}{l}4 \text { maja w mieście Wielka Terniwka, w powiecie olhopolskim, doszło } \\
\text { do wystąpienia przeciwko ustrojowi Państwa Ukraińskiego. }\end{array}$ & $\begin{array}{l}\text { Śledczy sądowy powiatu } \\
\text { olhopolskiego }\end{array}$ & Brak informacji. \\
\hline
\end{tabular}

Źródło: ЦДАВОВУ, ф. 2207, о. 1, сп. 825, Відомость № 2 про найбільшважні карні злочинства, заподіяні в межах Української Держави. Складена I Департаментом Міністерства Юстіціi 12 Серпня 1918 року, по представленням осіб прокурорського догляду, надісланним до Міністерства за від 4 по 10 серпня 1918 року, k. 5-8. 
Tabela 3. Wykaz najpoważniejszych zbrodni dokonanych na terytorium Państwa Ukraińskiego w okresie 11-18 sierpnia 1918 r.

\begin{tabular}{|c|c|c|c|}
\hline $\begin{array}{l}\text { Dzień } \\
\text { rozpoczęcia } \\
\text { postępowania }\end{array}$ & Opis przestępstwa & $\begin{array}{l}\text { Przynależność } \\
\text { okręgowa śledczego } \\
\text { sądowego }\end{array}$ & $\begin{array}{l}\text { Środki zapobiegawcze użyte } \\
\text { przez organy ścigania i stan } \\
\text { postępowania na dzień } \\
\text { sporządzenia wykazu }\end{array}$ \\
\hline 7 sierpnia $1918 \mathrm{r}$. & $\begin{array}{l}\text { W nocy z } 5 \text { na } 6 \text { sierpnia doszło do napadu na mieszkanie naczelnika War- } \\
\text { ty Państwowej w powiecie niżyńskim. Ataku dokonała banda Kropywlan- } \\
\text { skiego. Życie stracili naczelnik, } 10 \text { członków Warty Państwowej, a } 6 \text { zostało } \\
\text { rannych. }\end{array}$ & $\begin{array}{l}\text { Śledczy sądowy powia- } \\
\text { tu niżyńskiego }\end{array}$ & Brak informacji. \\
\hline 9 sierpnia $1918 \mathrm{r}$. & $\begin{array}{l}9 \text { sierpnia oddział powstańczy niejakiego Kropywlanskiego, w sile ok. } 600 \\
\text { osób, zaatakował w mieście Niżyn budynek starostwa powiatowego, komen- } \\
\text { danturę Warty Państwowej, sotnię wartowniczą oraz niemiecki sztab, który } \\
\text { przebywał na stacji kolejowej. Atak został odparty. Poległo } 24 \text { napastników, } \\
6 \text { niemieckich żołnierzy i kilkoro pasażerów pociągu. Ranny został } 1 \text { żołnie- } \\
\text { rzy sotni wartowniczej. }\end{array}$ & $\begin{array}{l}\text { Śledczy sądowy powia- } \\
\text { tu niżyńskiego }\end{array}$ & Brak informacji. \\
\hline 7 sierpnia $1918 \mathrm{r}$. & $\begin{array}{l}6 \text { sierpnia naczelnik Warty Państwowej w powiecie równieńskim został ra- } \\
\text { niony podczas wykonywania obowiązków służbowych. }\end{array}$ & Brak informacji. & $\begin{array}{l}\text { Prowadzono postępowanie } \\
\text { przygotowawcze. }\end{array}$ \\
\hline 9 sierpnia $1918 \mathrm{r}$. & 22 lipca w żytomierskim więzieniu doszło do próby ucieczki. & $\begin{array}{l}\text { Sędzia śledczy powiatu } \\
\text { żytomierskiego }\end{array}$ & Ucieczka nie powiodła się. \\
\hline 9 sierpnia $1918 \mathrm{r}$. & $\begin{array}{l}13 \text { lipca we wsi Potoki, w powiecie kaniowskim, doszło do wybuchu powsta- } \\
\text { nia lokalnych włościan przeciwko Hetmanatowi. W wyniku buntu stracił ży- } \\
\text { cie naczelnik Warty Państwowej w powiecie kaniowskim. } 15 \text { lipca doszło do } \\
\text { napaści na miasto Chodorów, gdzie zgładzono urzędnika, ograbiono domy } \\
\text { kilku mieszkańców i skradziono powiatowy telefon. Ponadto na terenie wło- } \\
\text { ści macedońskiej, chodorowskiej i pszenicznikowskiej występowano prze- } \\
\text { ciwko obecności wojsk niemieckich na Ukrainie. }\end{array}$ & Brak informacji. & Brak informacji. \\
\hline 14 sierpnia $1918 \mathrm{r}$. & $\begin{array}{l}\text { W kwietniu } 1918 \text { r. włościanie ze wsi Pyłypowice sformowali antyhetmański } \\
\text { oddział powstańczy. }\end{array}$ & $\begin{array}{l}\text { Sędzia śledczy powiatu } \\
\text { radomyślskiego }\end{array}$ & Brak informacji. \\
\hline
\end{tabular}

Źródło: ЦДАВОВУ, ф. 2207, о. 1, сп. 825, Відомость № 3 про найбільшважні карні злочинства, заподіяні в межах Української Держави. Складена I Департаментом Міністерства Юстіціi, [brak daty dziennej] Серпня 1918 року, по представленням осіб прокурорського догляду, надісланним до Міністерства за від 11 по 18 серпня 1918 року, k. 9-12. 
Tabela 4. Wykaz najpoważniejszych zbrodni dokonanych na terytorium Państwa Ukraińskiego w okresie od 19-27 sierpnia 1918 r.

\begin{tabular}{|c|c|c|c|}
\hline $\begin{array}{c}\text { Dzień } \\
\text { rozpoczęcia } \\
\text { postępowania }\end{array}$ & Opis przestępstwa & \begin{tabular}{|c|}
$\begin{array}{c}\text { Przynależność } \\
\text { okręgowa śledczego } \\
\text { sądowego }\end{array}$ \\
\end{tabular} & $\begin{array}{c}\text { Środki zapobiegawcze użyte przez organy } \\
\text { ścigania i stan postępowania na dzień } \\
\text { sporządzenia wykazu }\end{array}$ \\
\hline $\begin{array}{l}15 \text { sierpnia } \\
1918 \mathrm{r} \text {. }\end{array}$ & $\begin{array}{l}\text { W nocy z } 26 \text { na } 27 \text { lipca pociąg pasażersko-pocztowy wypadł } \\
\text { z torów między stacjami Sitkowice-Samczyce. Zginął } 1 \text { pasażer, } \\
3 \text { zostało ciężko rannych ( } 2 \text { z nich potem umarło). Lekko ran- } \\
\text { nych było } 19 \text { osób. }\end{array}$ & $\begin{array}{l}\text { Śledczy Sądu Okręgo- } \\
\text { wego w Winnicy }\end{array}$ & $\begin{array}{l}\text { Pociągnięci do odpowiedzialności karnej } \\
\text { zostali pomocnik naczelnika stacji Switłycki } \\
\text { i urzędnik kolei Melnyk. }\end{array}$ \\
\hline $\begin{array}{l}13 \text { sierpnia } \\
1918 \mathrm{r} .\end{array}$ & $\begin{array}{l}30 \text { lipca we wsi Krowne, w powiecie sumskim, włościanie Iwan } \\
\text { Andrijasz i Teodozjusz Balij wystąili na zebraniu wiejskim } \\
\text { przeciwko władzom Państwa Ukraińskiego. }\end{array}$ & $\begin{array}{l}\text { Wyznaczono śled- } \\
\text { czego. Brak szerszych } \\
\text { informacji }\end{array}$ & Brak informacji. \\
\hline $\begin{array}{l}10 \text { sierpnia } \\
1918 \mathrm{r} .\end{array}$ & $\begin{array}{l}1 \text { lipca włościanie ze wsi Zarudia, w powiecie krzemienieckim, } \\
\text { zamordowali krzemienieckiego notariusza Stepana Hulianickie- } \\
\text { go. }\end{array}$ & $\begin{array}{l}\text { Śledztwo rozpoczęto. } \\
\text { Brak szerszych infor- } \\
\text { macji }\end{array}$ & Sprawcy nie zostali zatrzymani. \\
\hline $\begin{array}{l}\text { Brak informacji } \\
{[\text { sic! }]}\end{array}$ & \begin{tabular}{|l|} 
W nocy 1 sierpnia we wsi Mokiewicze, w powiecie łochwickim, \\
10 uzbrojonych mężczyzn zaatakowało budynek poczty.
\end{tabular} & $\begin{array}{l}\text { Śledczy sądowy po- } \\
\text { wiatu łochwickiego }\end{array}$ & $\begin{array}{l}\text { Złoczyńcy zbiegli z miejsca zbrodni, nim } \\
\text { zostali rozpoznani. }\end{array}$ \\
\hline $\begin{array}{l}14 \text { sierpnia } \\
1918 \mathrm{r} \text {. }\end{array}$ & $\begin{array}{l}\text { W nocy na } 26 \text { lipca na stacji kolejowej Konotop był wybuch. } \\
\text { Ruch nie został wstrzymany, obyło się bez ofiar. }\end{array}$ & $\begin{array}{l}\text { Śledczy sądowy po- } \\
\text { wiatu konotopskiego }\end{array}$ & Brak informacji. \\
\hline $\begin{array}{l}20 \text { sierpnia } \\
1918 \mathrm{r} .\end{array}$ & $\begin{array}{l}12 \text { sierpnia w mieście Werbowiec na targu grupa włościan zaata- } \\
\text { kowała austriackich żołnierzy i jednego z nich zabiła. }\end{array}$ & Brak informacji. & $\begin{array}{l}\text { Jako prowodyra grupy zidentyfikowano nie- } \\
\text { jakiego Samborskiego. Wykorzystano wa- } \\
\text { chlarz środków do odnalezienia pozostałych } \\
\text { sprawców. }\end{array}$ \\
\hline $\begin{array}{l}\text { Brak informacji. } \\
{[s i c !]}\end{array}$ & $\begin{array}{l}15 \text { sierpnia w mieście Murowane Kuryłowice, w powiecie mo- } \\
\text { gileńskim, zatrzymano włościanina Tychołaza, który prowadził } \\
\text { agitację antypaństwową, nawoływał do powstania. Znaleziono } \\
\text { przy nim karabin z nabojami oraz bombę. Został schwytany } \\
\text { przez Austriaków i powieszony. }\end{array}$ & Brak informacji. & $\begin{array}{l}\text { Śledztwo w toku, poszukiwano pozostałych } \\
\text { uczestników spisku. }\end{array}$ \\
\hline
\end{tabular}

Źródło: ЦДАВОВУ, ф. 2207, о. 1, сп. 825, Відомость № 4 про найбільшважні карні злочинства, заподіяні в межах Української Держави. Складена I Департаментом Міністерства Юстіціi 27 Серпня 1918 року, по надісланним до Міністерства представленням осіб прокурорського догляду, k. 13-14; ibidem, Відомость № 4 про найбільшважні карні злочинства, заподіяні в межах Української Держави. Складена I Департаментом Міністерства Юстіціі 27 Серпня 1918 року, по надісланним до Міністерства представленням осіб прокурорського догляду, k. 15-16. 
Na podstawie treści wykazów można wyciągnąć wniosek, iż w oczach rządu Państwa Ukraińskiego za najpoważniejsze zbrodnie uważano: napaść na przedstawicieli władz Państwa Ukraińskiego (2 przypadki), powstania zbrojne i napaści na żołnierzy, urzędników i funkcjonariuszy Warty Państwowej Państwa Ukraińskiego oraz żołnierzy państw czwórprzymierza (14), krytykę antypaństwową lub zwróconą przeciwko państwom centralnym (7), terroryzm (6), strajki (1), rabunki, grabieże i defraudacje w bardzo dużych rozmiarach (4), przypadki demoralizacji funkcjonariuszy państwowych i samorządowych (szczególnie Warty Państwowej; 3), morderstwa znaczniejszych mieszkańców poszczególnych powiatów (4).

Nie wszystkie wymienione wyżej czyny zabronione spełniały klasyczne kryterium zbrodni. Występki takie jak kradzież rozbójnicza lub przywłaszczenie pieniędzy publicznych również zaliczono do tej niechlubnej kategorii (4 przypadki). Zdziwienie może również budzić stosunek Ministerstwa Sprawiedliwości do takich form protestu społecznego, jak strajki. Co prawda w wykazach odnotowano tylko jeden przypadek tego typu, ale wskazuje to mimo wszystko na pewną tendencję władz w postrzeganiu oporu społecznego, o czym wspomniano wyżej. W okresie ukraińskiej rewolucji narodowej 1917-1921 zwolennicy postępowych zmian taką postawę określiliby mianem „reakcyjnej”.

Należy jednak podkreślić, iż wykazy nie były kompletne. Pominięto w nich wiele przypadków zbrodni dokonanych w tym samym czasie na terytorium Państwa Ukraińskiego. Zgodnie z ustalonym wyżej kluczem powinny one zostać umieszczone $\mathrm{w}$ omawianych dokumentach. Poniżej przedstawiłem przypadki przestępstw, które są bardzo podobne (z uwagi na skutki, sprawców lub zagrożenie dla Państwa Ukraińskiego) do tych wymienionych w wykazach, ale z niewiadomych powodów zostały pominięte przez urzędników I Departamentu Ministerstwa Sprawiedliwości.

Na początku sierpnia 1918 r. w wyniku spontanicznego pościgu za 2 uzbrojonymi członkami grupy przestępczej (Iwan Maksymenko, 21 lat i Iwan Krasnenko, 19 lat) zginęli agent Warty Państwowej ps. Luty i posterunkowy Połowiecki. Obu przestępców udało się schwytać. $Z$ racji ich związków ze światem przestępczym oraz za zabicie członków milicji i wydziału kryminalnego kijowskiej Warty Państwowej zdecydowano o ich przekazaniu sądownictwu wojskowemu. Wraz z nimi sądzony miał być udzielający im schronienia włościanin Prochor Dmytriew (48 lat) ${ }^{13}$. 16 sierpnia 1918 r. minister sprawiedliwości Romanow wyraził

13 ЦДАВОВУ, ф. 2207, о. 1, сп. 325. Pismo prokuratora kijowskiego Sądu Okręgowego do Ministra Sprawiedliwości w sprawie przekazania zabójców agenta Warty Państwowej pr. „Luty” i posterunkowego Połowieckiego do sądu wojskowego w j. ros., 10 sierpnia 1918 r., k. 7; ibidem, Telegram do prokuratora kijowskiego Sądu Okręgowego w sprawie przekazania 3 członków zorganizowanej grupy przestępczej sądowi wojskowemu w j. ros., 12 sierpnia 1918 r., k. 2; ibidem, Pismo Ministra Spraw Wewnętrznych Państwa Ukraińskiego do Ministra Sprawiedliwości dotycząca przekazania 3 członków zorganizowanej grupy przestępczej sądowi wojskowemu w j. ukr., 13 sierpnia 1918 r., k. 3. 
zgodę na przekazanie postępowania w sprawie wyżej wymienionych sądownictwu wojskowemu ${ }^{14}$.

Inny interesujący przypadek dotyczył przestępstw dokonywanych przez przedstawicieli organów ścigania, w tym Warty Państwowej. 8 sierpnia pomocnik naczelnika tejże formacji na rejon (dzielnicę) płoski miasta Kijów, o nazwisku Zacharczenko, wraz z 2 posterunkowymi podłożył właścicielowi magazynu manufaktury, Ickowi Esełewskiemu, fałszywe „kierenki”15 o łącznej wartości 2 tys. karbowańców. Następnie szantażowali go i zmusili do wydania im 10 tys. karbowańców oraz 2 dużych fragmentów tkaniny. Po otrzymaniu pieniędzy i reszty dóbr Zacharczenko spalił fałszywą walutę oraz podzielił się karbowańcami i płótnem z posterunkowymi. Fakt, iż posiadali tak dużą sumę „kierenek”, pozwalał śledczym na wysnucie wniosku, iż sprawcy mieli dostęp do jeszcze większego zasobu fałszywej waluty. Zacharczenko, Dawidenko i Łatyszew powinni zostać przekazani sądowi wojskowemu zgodnie z decyzją Rady Ministrów z 26 lipca 1918 r. Postępowaniu nadano $\mathrm{nr} 336^{16}$. Jednak w wyniku nieudolności (albo w porozumieniu $\mathrm{z}$ nimi?) wartowników cała trójka zbiegła w niejasnych okolicznościach. Zacharczenko uciekł jako pierwszy, a Dawidenko i Łatyszew zbiegli wartownikom 15 sierpnia na Łukianowskim Bazarze w trakcie eskortowania ich $z$ więzienia ${ }^{17}$. Nieco później minister sprawiedliwości stwierdził, że czyny Zacharczenki i reszty nie spełniają kryteriów pozwalających na przekazanie ich sądownictwu wojskowemu ${ }^{18}$.

30 lipca rodzina Jeremynów (Eliasz, jego żona Marina, wnuk Andrij) z chutoru Boroczkynia (gubernia charkowska) została zamordowana przez mieszkańców włości sokołowskiej, powiatu zmijewskiego: Stepana Szemeta, Iwana Szemeta, Wasyla Kowałenkę, Dmytra Oboznego, Kuźmę Maksymenka, Ołeksija Szemeta, Pawła Charczenkę, Iwana Łabunskiego, Mykołę Jefremenka, Sawę Oboznego, Pantelejmona Mokienka, Iwana Jermołenkę i Harasyma Pliaka. Bandą kierowali Nikanor Hadiuszka i Harasym Pliak. W zbrodni i rabunku wziął również udział Roman Żukow, posterunkowy ze wsi złoczyńców, który również dostarczył Maksymence naboje do rewolweru Nagant. Oprócz Hadiuszka, Mokienki, Jermołenki i Iwana Pliaka, pozostałych zatrzymano i osadzono w więzieniu w Zmijence. Harasyma Pliaka Niemcy wysłali do charkowskiego więzienia. Wszyscy mieli zostać przekazani ukraińskiemu sądowi wojskowemu z uwagi na okrucieństwo

14 Ibidem, Zgoda Ministra Sprawiedliwości Romanowa na przekazanie sądownictwu wojskowemu 3 członków zorganizowanej grupy przestępczej w j. ukr., 16 sierpnia 1918 r., k. 4.

15 Kierenki - ruble emitowane przez rosyjski Rząd Tymczasowy w 1917 r.

16 ЦДАВОВУ, ф. 2207, о. 1, сп. 325, Pismo Ministra Spraw Wewnętrznych Państwa Ukraińskiego do Ministra Sprawiedliwości dotycząca przekazania 1 członka Warty Państwowej i 2 posterunkowych milicji sądowi wojskowemu w j. ukr., 17 sierpnia 1918 r., k. 5.

17 Ibidem, Pismo prokuratora kijowskiego Sądu Okręgowego do Ministerstwa Sprawiedliwości w sprawie ucieczki oskarżonych w sprawie nr 336 w j. ros., 9 września 1918 r., k. 12-13.

18 Ibidem, Pismo Ministra Sprawiedliwości do Ministra Spraw Wewnętrznych w kwestii przekazania oskarżonych ze sprawy 336 sądownictwu wojskowemu w j. ukr., 16 września 1918 roku, k. 18. 
$\mathrm{w}$ trakcie dokonanego napadu $\mathrm{z}$ rabunkiem ${ }^{19}$. Ostatecznie jednak minister sprawiedliwości nie zdecydował się na przekazanie postępowania przed sądownictwo resortu wojskowego, o czym można się dowiedzieć $\mathrm{z}$ innych dokumentów ${ }^{20}$.

W przypadku powyższej zbrodni o konieczności pojawienia się jej w wykazach decydowały dwa fakty - dokonanie okrutnej zbrodni zbiorowego mordu w połączeniu $\mathrm{z}$ grabieżą oraz udział przedstawiciela organów ścigania $\mathrm{w}$ przestępstwie. Stąd rodzi się pytanie, dlaczego powyższe wydarzenie nie zostało wymienione w wykazach? Można podejrzewać, że o pominięciu zadecydował fakt aresztowania posterunkowego Żukowa. Niemniej w wielu dokumentach pojawiały się i takie postępowania, w których organy ścigania poczyniły już znaczące postępy w śledztwach, przykładowo aresztując sprawców lub podejrzanych.

Władze Państwa Ukraińskiego niepokoiły również wszelkie przypadki występowania przeciwko ich autorytetowi. Kolejny przykład dotyczy właśnie takiego przestępstwa, które jednak nie zostało wspomniane w omawianych wykazach. 5 sierpnia Iwan Dmytrenko podczas rekrutowania poborowych w jednym z powiatów guberni charkowskiej nawoływał poborowych do bojkotu służby wojskowej. Następnie zebrał grupę 75 mężczyzn, którzy wyruszyli z nim do siedziby naczelnika wojskowego. Poborowych zatrzymali jednak wartownicy, a sam Dmytrenko został aresztowany. Minister spraw wewnętrznych uznał, iż postępowanie w tej sprawie powinno zostać przekazane sądownictwu wojskowemu z powodu krytyki wymierzonej we władze Państwa Ukraińskiego i zakłócania porządku²1.

Inny pominięty w wykazach I Departamentu przypadek wystąpienia antyhetmańskiego miał miejsce w powiecie Kamieniec Podolski pod koniec lipca $1918 \mathrm{r}$. Aresztowano wtedy na dwa tygodnie 10 mieszkańców wsi Werbki i Pryworotia. Dowodem przeciwko nim były przechwycone przez Wartę Państwową listy. 27 lipca naczelnik Powiatowej Warty Państwowej poprosił w swym liście o przedłużenie nałożonego na agitatorów aresztu do jednego miesiąca. Dalszy tok sprawy niestety nie jest mi znany ${ }^{22}$.

19 Ibidem, Pismo Ministra Spraw Wewnętrznych Państwa Ukraińskiego do Ministra Sprawiedliwości w sprawie przekazania morderców rodziny Jeremynów sądownictwu wojskowemu w j. ukr., 12 września 1918 r., k. 16. W jego trakcie ranna została Maryna, córka Eliasza, zob. ibidem.

20 Ibidem, Pismo Ministra Spraw Wewnętrznych do Ministra Sprawiedliwości w kwestii ponownego rozpatrzenia przekazania sprawy o zabójstwo rodziny Eliasza Jeremina sądownictwu wojskowemu w j. ukr., 4 października 1918 r., k. 25; ibidem, Odpowiedź Ministra Sprawiedliwości Ministrowi Spraw Wewnętrznych w kwestii odmowy o przekazaniu morderców rodziny Eliasza Jeremina jurysdykcji sądów wojskowych w j. ukr., 16 października 1918 r., k. 26.

${ }^{21}$ Ibidem, Pismo Ministra Spraw Wewnętrznych Państwa Ukraińskiego do Ministra Sprawiedliwości w sprawie przekazania agitatora Iwana Dmytrenki sądownictwu wojskowemu z dnia 12 września 1918 roku w j. ukr., k. 15; ibidem, Pismo Ministra Sprawiedliwości do Ministra Spraw Wewnętrznych w kwestii przekazania Iwana Dmytrenki sądownictwu wojskowemu w j. ukr., 16 września 1918 r., k. 17.

22 Ibidem, ф. 1793, o. 1, сп. 47, List Naczelnika Powiatowej Warty Państwowej w Kamieńcu Podolskim w j. ukr., 27 lipca 1918 r., k. 4. 
Warto również wspomnieć o tym, że w wykazach wymieniono bardzo małą liczbę lokalnych powstań i aktów oporu wymierzonych przeciwko Państwu Ukraińskiemu i wojskom państw centralnych na Ukrainie. Większość buntów wybuchła właśnie latem 1918 r., więc tym bardziej dziwi fakt, iż w omawianych dokumentach I Departamentu wskazano ich tak niewiele. Podobnie rzecz wygląda ze strajkami wśród ukraińskich kolejarzy - zaczęły się pod koniec czerwca, a do ich intensywnego zwalczania Niemcy przystąpili dopiero na początku sierpnia. Dziwny jest również brak informacji $\mathrm{w}$ wykazie o fakcie wysadzenia $\mathrm{w}$ powietrze magazynu rosyjskiej amunicji na stacji kolejowej w Maniewiczach 9 sierpnia 1918 r. $^{23}$

Moją uwagę zwrócił także fakt, że wykazy przygotowywano od niemal tego samego momentu, co raporty Warty Państwowej, które sporządzano od końca lipca 1918 r. Pracownicy I Departamentu Ministerstwa Sprawiedliwości z pewnością mieli kontakt z tymi dokumentami. Świadczy o tym fakt pojawienia się w wykazach resortu zbrodni, których przebieg i kontekst został bardziej szczegółowo opisany właśnie w raportach Warty Państwowej. Przygotowywano je niemal codziennie ${ }^{24}$.

23 Szerzej zob. W. Mędrzecki, op. cit., s. 241-245.

24 Агентурні відомості від 26 липня 1918. Сводка сведений, поступивших в Осведомительный отдел Департамента державной варты Министерства внутренних дел о настроении населения Украинской Державы за 23, 24 и 25 июля 1918 г[ода]; Агентурні відомості від 27 липня 1918. Сводка сведений, поступивших [...] за 25, 26 и 27 июля 1918 г[ода]; Агентурні відомості від 28 липня 1918. Сводка сведений, поступивших [...] за 25, 27 и 28 июля 1918 г[ода]; Агентурні відомості від 29 липня 1918. Сводка сведений, поступивших [...] за 26, 27, 28 и 29 июля 1918 г[ода]; Агентурні відомості від 31 липня 1918. Сводка сведений, поступивших [...] за 29, 30 и 31 июля 1918 г[ода]; Агентурні відомості від 1 серпня 1918 (1). Сводка сведений, поступивших [...] за 30 и 31 июля и 1 августа 1918 г[ода]; Агентурні відомості від 1 серпня 1918 (2). Сводка сведений, поступивших в [...] за 30 и 31 июля и 1 августа 1918 г[ода]; Агентурні відомості від 3 серпня 1918. Сводка сведений, поступивших [...] за 1 и 2 августа 1918 года; Агентурні відомості від 5 серпня 1918. Сводка сведений, поступивших [...] за 2 и 3 августа 1918 года; Агентурні відомості від 6 серпня 1918. Сводка сведений, поступивших [...] за 3 и 4 августа 1918 г[ода]; Агентурні відомості від 8 серпня 1918. Сводка сведений, поступивших [...] за 3, 5, 6 и 7 августа 1918 г[ода]; Агентурні відомості від 9 серпня 1918. Сводка сведений, поступивших [...] за 6, 7 и 8 августа 1918 г[ода]; Агентурні відомості від 12 серпня 1918. Сводка сведений, поступивших [...] за 9, 10 и 11 августа 1918 г[ода]; Агентурні відомості від 13 серпня 1918. Сводка сведений, поступивших [...] за 11 и 12 августа 1918 г[ода]; Агентурні відомості від 14 серпня 1918. Сводка сведений, поступивших [...] за 10, 11, 12 и 13 августа 1918 г[ода]; Агентурні відомості від 15 серпня 1918. Сводка сведений, поступивших [...] за 12, 13 и 14 августа 1918 года; Агентурні відомості від 16 серпня 1918. Сводка сведений, поступивших [...] за 14 и 15 августа 1918 г[ода]; Агентурні відомості від 17 серпня 1918. Сводка сведений, поступивших [...] за 14, 15 и 16 августа 1918 г[ода]; Агентурні відомості від 18 серпня 1918. Сводка сведений, поступивших [...] за 12, 16 и 17 августа 1918 года; Агентурні відомості від 20 серпня 1918 (1). Сводка сведений, поступивших [...] за 15, 16 и 17 августа 1918 г[ода]; Агентурні відомості від 20 серпня 1918 (2). Сводка сведений, поступивших [...] за 16, 17, 18 и 19 августа 1918 г[ода]; Агентурні відомості від 21 серпня 1918. Сводка сведений, поступивших [...] за 17, 18, 19 и 20 августа 1918 г[ода]; Агентурні відомості від 22 серпня 1918. Сводка сведений, поступивших [...] за 17, 20 и 21 августа 1918 года; Агентурні відомості від 23 серпня 
$\mathrm{Na}$ ich podstawie można się dowiedzieć, iż liczba zbrodni dokonanych na terytorium Państwa Ukraińskiego w omawianym okresie była znacznie większa, niż wskazywały na to wykazy. Informacje z obu typów źródeł zestawiłem w tabeli 5.

Tabela 5. Porównanie liczby zbrodni dokonanych na terytorium Państwa Ukraińskiego w oparciu o raporty Warty Państwowej i wykazy I Departamentu Ministerstwa Sprawiedliwości

\begin{tabular}{|l|c|c|c|}
\hline \multicolumn{1}{|c|}{$\begin{array}{c}\text { Typ } \\
\text { zbrodni }\end{array}$} & $\begin{array}{c}\text { W wykazach } \\
\text { I Departa- } \\
\text { mentu }\end{array}$ & $\begin{array}{c}\text { W raportach } \\
\text { Warty } \\
\text { Państwowej }\end{array}$ & $\begin{array}{c}\text { Procentowy stosunek } \\
\text { liczby zbrodni ujętych } \\
\text { w wykazach do liczby } \\
\text { wskazanej w raportach }\end{array}$ \\
\hline $\begin{array}{l}\text { Napaść na przedstawiciela władz } \\
\text { Państwa Ukraińskiego }\end{array}$ & 2 & 1 & 200 \\
\hline $\begin{array}{l}\text { Powstania zbrojne i napaści na żoł- } \\
\text { nierzy, urzędników i funkcjonariuszy } \\
\begin{array}{l}\text { Warty Państwowej Państwa Ukrain- } \\
\text { skiego oraz żołnierzy czwórprzymierza }\end{array}\end{array}$ & 14 & 153 & 9,15 \\
\hline $\begin{array}{l}\text { Krytyka antypaństwowa lub zwrócona } \\
\text { przeciwko państwom centralnym }\end{array}$ & 7 & 31 & 22,58 \\
\hline Terroryzm & 6 & 9 & 66,66 \\
\hline Strajki & 1 & 14 & 7,14 \\
\hline $\begin{array}{l}\text { Rabunki, grabieże i defraudacje } \\
\text { o bardzo dużych rozmiarach }\end{array}$ & 4 & 15 & 26,66 \\
\hline $\begin{array}{l}\text { Przypadki demoralizacji funkcjona- } \\
\text { riuszy państwowych i samorządowych } \\
\text { (szczególnie Warty Państwowej) }\end{array}$ & 3 & 12 & 25 \\
\hline $\begin{array}{l}\text { Morderstwa znaczniejszych mieszkań- } \\
\text { ców poszczególnych powiatów }\end{array}$ & 4 & 9 & 44,44 \\
\hline
\end{tabular}

Jak widać, przeważnie liczba przestępstw ujętych w wykazach resortu sprawiedliwości nie sięgała nawet połowy liczby zbrodni opisanych w raportach organu ścigania i bezpieczeństwa. Szczególnie rażąco wygląda ten niedobór na przykładzie wrogiej działalności grup powstańczych $(9,15 \%)$ oraz strajków (zaledwie $7,14 \%)$,

1918. Сводка сведений, поступивших [...] за 20, 21 и 22 августа 1918 г[ода]; Агентурні відомості від 24 серпня 1918. Сводка сведений, поступивших [...] за 21, 22 и 23 августа 1918 года; Агентурні відомості від 25 серпня 1918. Сводка сведений, поступивших [...] за 22, 23 и 24 августа 1918 года; Агентурні відомості від 26 серпня 1918. Сводка сведений, поступивших [...] за 23, 24 и 25 августа 1918 года; Агентурні відомості від 27 серпня 1918. Сводка сведений, поступивших [...] за 24, 25, 26 и 27 августа 1918 г[ода]; Агентурні відомості від 28 серпня 1918. Сводка сведений, поступивших [...] за 26 и 27 августа 1918 г[ода]; Агентурні відомості від 31 серпня 1918 (1). Сводка сведений, поступивших [...] за 27, 28, 29 и 30 августа 1918 г[ода]; Агентурні відомості від 31 серпня 1918 (2). Сводка сведений, поступивших [...] за 29, 30 и 31 августа 1918 г[ода]; Агентурні відомості від 1 вересня 1918. Сводка сведений, поступивших [...] за 31 августа и 1 сентября 1918 г[ода], w: Архів Української Народної Республіки..., s. 16-63. 
głównie na kolei. Zarazem w jednym przypadku - zamachów na przedstawicieli władz Państwa Ukraińskiego - wykazy zawierały więcej informacji niż raporty Warty Państwowej. W dokumentach tego organu ścigania pomięto informację o nieudanym ataku na ministra transportu Borysa Butenkę.

Ciężko stwierdzić, jakie czynniki spowodowały, iż właśnie wyżej wymienione przypadki pracownicy I Departamentu Ministerstwa Sprawiedliwości umieścili w przygotowanych przez siebie dokumentach. Z pewnością czynnikiem decydującym nie był stan, w jakim znajdowało się aktualnie postępowanie. Na dodatek $\mathrm{w}$ wielu przypadkach brakowało informacji na ten temat, jak również o śledczym wyznaczonym do prowadzenia śledztwa. W niektórych wykazach znalazły się informacje o przestępstwach, które zostały dokonane kilka miesięcy przed sporządzeniem pierwszego raportu, a więc wykraczały poza narzucone przez autorów dokumentów cezury. Wykazy wyglądają na chaotyczny zbiór informacji o wybranych zbrodniach. Nie może on stanowić samodzielnego źródła do badania zagadnienia przestępczości i działalności antyrządowej na terytorium Państwa Ukraińskiego w $1918 \mathrm{r}$.

Niemniej omawiane dokumenty Ministerstwa Sprawiedliwości pozwalają dostrzec szereg interesujących szczegółów. Wskazują choćby na to, jakie typy przestępstw były popełniane na terytorium Państwa Ukraińskiego, a także, które z nich najmocniej niepokoiły Hetmanat. Ponadto wykazy mogą wiele powiedzieć o fachowości biurokratycznej poszczególnych urzędników administracji rządowej. Pod znakiem zapytania stoi to, czy w pozostałych resortach sytuacja kadrowa oraz informacyjna była lepsza? Powyższe stanowi kolejny argument dla tych badaczy, którzy poddają rewizji dosyć powszechny pogląd o tym, iż Hetmanat Skoropadskiego był oazą stabilności, fachowości i rozwoju na tle URL i Zachodnioukraińskiej Republiki Ludowej. Z przedstawionych wyżej dokumentów wyłania się bardziej złożony obraz funkcjonowania Państwa Ukraińskiego, jak i życia codziennego zwykłych ukraińskich obywateli, którzy mimo odsunięcia od władzy mało kompetentnej Centralnej Rady nadal stykali się z przemocą i bezprawiem.

\section{Crime in the Ukrainian State between the End of July and August 1918 - An Analysis Based on Selected Materials from the Central State Archives of Supreme Bodies of Power and Government of Ukraine in Kyiv}

\section{Abstract}

Following the treaty concluded on 9 February 1918 in Brest-Litovsk, the German and Austro-Hungarian Armies entered Ukraine as its allies in the war against Bolsheviks. Relations between the Quadruple Alliance states and the Ukrainian People's Republic, however, were not harmonious. For this reason, the Germans supported a coup by Pavlo Skoropadsky. As the coup's result, the Ukrainian People's Republic was replaced by the Ukrainian State. It was headed by Skoropadsky himself, who took on the title of hetman. 
According to a popular in Ukraine opinion, the Hetmanate period was the time of stabilisation and order. Some researchers indicate the fact that under Skoropadsky, the Ukrainian judicial system was developed, as well as the education system, culture, and even that of the armed forces. For this purpose, they compare the Ukrainian State with the Ukrainian People's Republic led by the Central Council at the turn of 1918, and by the Directorate during an exceptionally bloody period between December 1918 and November 1920. Indeed, presented against such a background, Hetman Skoropadsky's rule seems to be an oasis of peace, development, and order. Detailed archival research, however, tarnishes this idealised image.

The image based on archival materials kept in the Ukrainian institutions reveals the Ukrainian State trying to fight against lawlessness, but with no success. The presence of Central State armies was not always favourable to bringing order on the Dnieper, especially that there were many Ukrainians hostile towards German and Austro-Hungarian troops. The search query makes it also possible to notice discrepancies and information disorder in documents prepared by different departments of the Ukrainian State government, including the Ministry of Justice.

\section{Преступность в Украинской Державе в период с конца июля - август 1918 г. - анализ на основании избранных материалов Центрального государственного архива высших органов власти и администрации Украины в Киеве}

\section{Аннотация}

В результате договора, заключенного 9 февраля 1918 г. в Брест-Литовске немецкая и австро-венгерская армии вошли в Украину как ее союзники в войне против большевиков. Однако отношения между государствами Четверного союза и Украинской Народной Республикой складывались не лучшим образом. Из-за этого Германия 29 апреля поддержала государственный переворот, совершенный ген. Павлом Скоропадским. В результате чего, вместо демократической Украинской Народной Республики была создана Украинская Держава. Возглавил ее сам Скогопадский, присваивая себе звание гетмана.

На Украине довольно распространено мнение, что период Гетманата - это время стабильности и порядка. Часть исследователей указывает на то, что при Павле Скоропадском развились украинское правосудие, образование, культура и даже военное дело. Украинская Держава, при этом, сопоставляется с Украинской Народной Республикой, управляемой Центральной Радой на переломе 1917-1918 гг., а также Директорией в особенно кровавый для Украины период с декабря 1918 г. по ноябрь 1920 г. На их фоне правление гетмана Скоропадского действительно кажется «оазисом» упомянутых развития и порядка. Однако скрупулёзные архивные исследования рушат этот идеализированный образ.

На основании архивных материалов, хранящихся в украинских учреждениях, вырисовывается образ государства, пытавшегося бороться с беззаконьем, но не очень преуспевающего на этом поприще. Наведению порядка над Днепром также не всегда способствовало присутствие войск Центральных государств, особенно, что многие украинцы относились враждебно к немецким и австро-венгерским солдатам. Архивный розыск дал также возможность заметить проблему непоследовательности и информационного хаоса в документах, подготовляемых разными ведомствами правительства Украинской Державы, включая Министерство юстиции. 


\section{Bibliografia}

\section{Źródła}

Центральний Державний Архів Вищих Органів Влади та Управління України у Києві (ЦДАВОВУ)

Подільський губернський староста Української держави, м. Вінниця (фонд 1793)

Міністерство юстиції Української Держави Київ (фонд 2207)

Архів Української Народної Республіки. Міністерство внутрішніх справ. Звіти департаментів державної варти та політичної інформації (1918-1922), упор. В. Кавунник, Київ 2018.

Бій під Крутами в національній пам'яті. Збірник документів і матерліалів, ред. О. Любовець, О. Березовський, С. Бутко, А. Тищенко, І. Цимбал, Київ 2013.

Л-ий І. [Лоський Ігор], Крути, „Літопис Червоної Калини” (1932), № 2, s. 2-5.

Скоропадський П., Спогади. Кінець 1917-грудень 1918, Київ-Філадельфія 1995.

Українська Держава (квітень-грудень 1918 року). Документи і матеріали. У двох томах, т. 1-2, ред. В. Смолій, Київ 2015.

Украйнська Центральна Рада. Документи і матеріали. У двох томах, т. 2: 10 грудня 1917 р. - 29 квітня 1918 р., ред. В. Верстюк, Київ 1997.

\section{Opracowania}

Mędrzecki W., Niemiecka interwencja militarna na Ukrainie w 1918 roku, Warszawa 2000.

Skrukwa G., Formacje wojskowe ukraińskiej „rewolucji narodowej” 1914-1921, Toruń 2008.

Гай-Нижник П., Фінансова політика уряду Української Держави Гетьмана Павла Скоропадського (29 квітня 14 грудня 1918 р.), Київ 2001.

Героїка трагедї Крут, ред. В. Сергійчук, М.І. Сергійчук, Київ 2008.

Головченко В., Солдатенко В., Українське питання в роки Першої світової війни, Київ 2009.

Гончаренко А., Бій під Крутами, „За державність” 9 (1939), s. 145-152.

Гуцалюк І., Суд та судочинство в Західній Волині за Гетьманату П. Скоропадського, „Науковий вісник Волинського національного університету імені Лесі Українки. Історичні науки” (2010), № 1.

Дорнік В., Касьянов Г., Ліб П., Ляйдінгер Г., Міллєр А., Мусял Б., Расевич В., Україна між самовизначенням та окупацією: 1917-1922 роки, Київ 2015.

Дорошенко Д., Історія України 1917-1923 рр., т. 2: Украйнська Гетьманська Держава 1918 р., Київ 2002.

Крезуб А. [Думін Осип], „Українські Термопілі” (в десяту річницю бою під Крутами), „Літературно-Науковий Вістник” 28 (1928), № 2, s. 105-109.

Крути 29 січня 1918 р., ред. О. Бойко, Київ 2007.

Кущинський А., Патріот і державний муж України. У 100-річчя з дня народження Гетьмана усієї Украӥни і Військ Козацьких Павла Скоропадського та 55-ої річниці відновлення Української Традиційної Гетьманської Держави, Чикаго 1974.

Панакін Г., Павло Скоропадський. патріот, державотворець, людина. Історико-архівні нариси, Київ 2003.

Пиріг Р., Українська гетманська держава 1918 року. Історичні нариси, Київ 2011.

Рум'янцев В., Судова система в Украйнській державі гетьмана П. Скоропадського, „Вісник Академії правових наук України” (2001), № 2 (25). 
Терещенко Ю., Гетьманат Павла Скоропадського як прояв консервативної революції, w: Гетьманат Павла Скоропадського. історія, постаті, контроверсіі. Всеукраїнська наукова конферениія 19-20 травня 2008 р., ред. В. Верстюк, Київ 2008.

Тимощук О., Державна варта Української Держави (історико-юридичний аналіз), Київ 1998.

Тинченко Я., Українські зброцні сили: березень 1917 - листопад 1918 р. (організація, чисельність, бойові діi), Київ 2009.

Удовиченко О., Загибель студентського куреня під Крутами, „Військова Справа” (1928), № 2, s. 5-8.

Феденко П., Влада Павла Скоропадского (пятьдесяті роковини перевороту в Україні), Лондон-Мюнхен 1968.

Фіголь А., Бій під Крутами, „Літопис Червоної Калини” (1931), № 2, s. 2-6.

Яневський Д., Проект „Украйна” або спроба Павла Скоропадського, Харків 2010.

Marek Bogdan Kozubel, dr; w 2013 r. na Uniwersytecie Mikołaja Kopernika w Toruniu obronił rozprawę doktorską pt. Dzieje Ukraińskich Strzelców Siczowych w latach 1914-1920. Obecnie pracuje w Instytucie Pamięci Narodowej. Jego zainteresowania naukowe koncentrują się wokół dziejów krajów Europy Wschodniej, ze szczególnym uwzględnieniem historii Polski, Rosji oraz Ukrainy (mkozubel@wp.pl).

Marek Bogdan Kozubel, PhD in history (2013) at the same University, after defending the dissertation on the history of Ukrainian Sich riflemen in 1914-1920 (Dzieje Ukrainskich Strzelców Siczowych $w$ latach 1914-1920). Currently works at the Institute of National Remembrance. He specialises in the history of Eastern European countries, especially in of Ukraine and Polish-Ukrainian and Russian-Ukrainian relations (mkozubel@wp.pl). 